\title{
Tax aggressiveness of family firms in emerging countries: How does resource-based view explain it?
}

\author{
Usil Sis Sucahyo, Theresia Woro Damayanti, \\ Ronny Prabowo, Supramono Supramono
}

\begin{abstract}
A B S T R A C T
Objective: The objective of the article is to empirically examine the effects of three resource categories based on the resource-based view - represented by firm size, top manager's experience, and closeness to governments - on family firms tax aggressiveness in emerging countries.

Research Design \& Methods: The study used data from the World Bank's Productivity and the Investment Climate Survey that covers several issues, including taxation. The survey was held in 2006-2018. We use data from 19848 family firms as our sample. Data is analysed with the Ordered Probit Model.
\end{abstract}

Findings: The results of the analysis showed that family firms with resources of firm size, top manager's better experience, and closeness to government have the options to engage in greater tax aggressiveness than other family firms.

Implications \& Recommendations: The governments of emerging countries need to pay more attention to larger family firms and the firms led by more experienced top managers to enhance tax compliance because these firms potentially engage in greater level of tax aggressiveness.

Contribution \& Value Added: This study offers a better understanding of the tax aggressiveness of family firm that is relatively poorly understood in the literature with the resource-based view approach.

\section{Article type: research article}

Keywords: tax aggressiveness; family firms (FFs); resource-based view (RBV); firm size; top manager's experience; closeness to governments JEL codes: L14, H26

Received: 15 January $2020 \quad$ Revised: 23 July $2020 \quad$ Accepted: 29 July 2020

\section{Suggested citation:}

Sucahyo, U.S., Damayanti, T.W., Probowo, R., \& Supramono, S. (2020). Tax aggressiveness of family firms in emerging countries: How does resource-based view explain it?. Entrepreneurial Business and Economics Review, 8(3), 101-115. https://doi.org/10.15678/EBER.2020.080306 


\section{INTRODUCTION}

In emerging economies, family firms (FFs) are considered to have significant economic impacts (Gedajlovic, Carney, Chrisman, \& Kellermsirmanns, 2012; Schulze \& Gedajlovic, 2010), because they can contribute to job creation and economic growth (Lucky, Minai, \& Isaiah, 2011), along with economic recovery during economic crisis (Bonilla, Sepulveda, \& Carvajal, 2010). Thus, it is understandable that governments pay much attention to FFs' development (Monticelli, 2017). Even Kim, Kandemir, and Cavusgil (2004) emphasize that the key factor of FFs' development is their closeness to governments, commonly labeled as political connections. According to the resource-based view (RBV), this closeness is indeed one of firms' resources included in the category of organizational resources.

However, closeness to government is often exploited by FFs for their interests, including tax purposes (Welter, 2011), by carrying out tax aggressiveness aimed at reducing their tax obligations. Tax aggressiveness itself is defined as intentional activities to avoid tax obligations and payments (Martinez, 2017). Tax aggressiveness can be done by companies through marking up costs or recording lower real revenue. It is possible that closeness to government is not the only resource that allows tax aggressiveness for FFs but also relates to other resources.

The resource-based view (RBV) classifies firms' resources into three categories, namely physical capital resources, human capital resources, and organizational resources (Barney, 1991; Michalisin, Smith, \& Douglas, 1997). Physical capital resources are firms' physically existing capital commonly indicated by firm size. Cabrera-Suárez, Déniz-Déniz, and Martín-Santana (2014), Huybrechts, Voordeckers, Lybaert, and Vandemaele (2016), and Smulders, Stiglingh, Franzsen, and Fletcher (2017) identify that firms' resources - as measured by firm size - negatively affect tax aggressiveness. Meanwhile, human capital resources refer to the characteristics of top management, such as experience, which also negatively affects tax aggressiveness behaviour (Bjuggren \& Sud, 2005; Smulders et al., 2017). Although the results of previous studies showed a negative effect, there remains a possibility that the size and experience of top management has a positive effect on tax aggressiveness. Larger FFs will also add tax burden so they tend to be more motivated to carry out tax aggressiveness. Likewise, with the experience of top management, increasingly experiencing a deeper understanding of the ins and outs of taxation including efforts to reduce tax liabilities so as to encourage top management to aggressively tax. The above arguments require further study.

The objective of the article is to empirically examine the effects of the three resource categories based on the RBV, namely physical capital resources, human capital resources, and organizational resources that are represented by firm size, top manager's experience, and closeness to governments on FFs' tax aggressiveness in emerging countries. This paper contributes to the literature by offering a better understanding of FFs' tax aggressiveness, which is relatively understudied, in at least two ways. Firstly, we analyse the issue from FFs' heterogeneous and unique resources and not from the agency perspective as do other studies. However, this study uses the RVB framework that has a prominent position in strategic management research because it provides a comprehensive explanation regarding the combination of firm's internal resources and capabilities as a key to achieving sustainable competitive advantage. Secondly, we add closeness to government as firm resources, which was 
analysed by previous studies. This study uses data from the World Bank's Productivity and Investment Climate Survey that covers several issues, including taxation. The survey was held in 2006-2018 with the total of 136889 respondents. We use only FFs from emerging countries as our sample that meet several criteria: firms with single ownership of more than $50 \%$ of total ownership and formal firm. The above criteria produce the final sample of 19848 firms. We test our hypothesis by using the ordered probit model (OPM).

The rest of the article is structured as follows. The second section presents the literature review and the theoretical arguments underlying the research hypotheses on the effects of firm size, top managers' experience, and closeness to governments on firms' tax aggressiveness. The third section presents the research data and methods. Next, the fourth section discusses the results of hypothesis testing. Lastly, the fifth section concludes and suggests future research directions.

\section{LITERATURE REVIEW}

Barney's article (1991) "Firm Resources and Sustained Competitive Advantage" was an important milestone for the RBV, commonly known as the resource-advantage theory. Principally, RBV considers firm as a collection of resources and capabilities. Differences in resources and capabilities from competitors create the competitive advantage of firms (Peteraf \& Barney, 2003). Firms develop their competitive advantage by utilizing and managing their resources productively to create valuable, rare, inimitable, and non-substitutable resources (Kabue \& Kilika, 2016). When firms operate in industries that do not facilitate them to develop inimitable or non-substitutable resources, they need to build competencies to convert imitable and substitutable resources into inimitable and non-substitutable resources so as to ensure sustainable competitive advantage. Thus, firms must be creative and entrepreneurs must create competitive advantage (Barney, 2001). Competence building is the product of organizational culture and values that will shape firms' behaviours.

Similarly in FFs, they must properly manage their resources in order to increase their competitive advantage. A family firm can be dominantly controlled by a family with the vision to potentially sustain family control across generations (Zellweger, 2017, pp. 98-99). This definition of a FF is in line with the definition conveyed by Chua, Chrisman, and Sharma (1999), which emphasizes two central attributes: the controlling family and control across generations. For dominant control interests to remain in the hands of the family, ownership or voting rights of more than $50 \%$ are required (Bednarz, Bieliński, Wołowik, \& Otukoya, 2017). Basically, the nature of FFs will be determined by the cultural and behavioural aspects introduced by the controlling family (Chrisman, Chua, \& Steier, 2005; Zellweger, Eddleston, \& Kellermanns, 2010). The intention of the founder of the family company is not only to create wealth that will only be enjoyed by the founder but has a vision to be passed to future generations. The existence of a family business is inseparable from the existence of several strengths and weaknesses. For example, Zellweger (2017, pp. 162) identifies the strengths of FFs, including lower agency costs, efficient leadership, continuity, and long-term orientation. Meanwhile, their weakness was high dependence on family and challenges of succession.

From the RBV perspective, firms' resources can be classified into three types, namely physical capital resources, human capital resources, and organizational resources (Barney, 1991; Michalisin et al., 1997). Firms need to interact with these three resource types 
to achieve their objectives. Enz (2008) argues that a resource does not suffice to build a competitive advantage. In this respect, firms need to organize various resources in certain ways to build capabilities in creating competitive advantage as the basis of firm behaviour. Firm size is often associated with reputation and information openness. Larger firms exhibit a better reputation (Waluyo, 2017). FFs' managers tend to avoid tax aggressiveness to protect their firms' long-term reputation (Isakov \& Weisskopf, 2015; SánchezMarín, Portillo-Navarro, \& Clavel, 2016). In terms of governance, relatively larger FFs likely have better governance than smaller ones. The argument is also supported by Madhani (2016) who shows the positive correlation between size and governance. Besides, larger firms have greater incentives to disclose information to reduce political cost because they attract public scrutiny (Eilbert \& Parket, 1973) and have sufficient resources to produce information. Better governance and more disclosed information disincentivize FFs to engage in tax aggressiveness.

However, it is possible that family firm size will positively impact tax aggressiveness with several arguments, including the fact that larger firms tend to have greater profits than smaller firms, and the tax burden is higher, which encourages firms to take actions to reduce their tax payments (Irianto, Sudibyo, \& Wafirli, 2017). The larger firms also have more complexity in their transactions, which provides more opportunities in the effort to avoid taxation (Rego, 2003). Moreover, the Political Power Theory - as initially proposed by Siegfried (1972) - also hypothesizes that larger firms have greater political power that they can use to engage in political negotiations to facilitate tax aggressiveness, and larger firms also have a better financial ability to hire tax experts to carry out tax planning. The above arguments receive support from previous studies conducted by Irianto et al. (2017), Ogbeide (2017), Wang, Campbell, and Johnson (2014), Nicodème (2007), Dyreng, Hanlon, and Maydew (2008), and Mills, Nutter, and Schwab (2013), which prove that firm size has a positive and significant influence on tax aggressiveness. Based on the above discussion, we propose the following hypothesis:

H1: Family firm size positively affects firms' tax aggressiveness.

RBV positions human capital resources as the source of sustainable competitive advantage. These human capital resources can be in the form of individual experiences in an organization. Several studies relate top managers' experience to firms' financial performance (Peni, 2014; Saidu, 2019). The results demonstrate the positive correlation between Chief Executive Officer's (CEO) experience and firm's financial performance. CEOs' longer experience also contributes to the reputation of CEOs and firms. More reputable CEOs are associated more with firms' resources than less reputable ones (Stanwick \& Stanwick, 2003; Wade, Porac, Pollock, \& Graffin, 2008). In the taxation context, FFs managed by more experienced CEOs will focus on their performance and reputation, so they are likely to exhibit lower tax aggressiveness.

There is also a reason that manager's experience is positively related to tax aggressiveness. Experienced managers can be associated with their ability to manage firm resources more efficiently. According to Koester, Shevlin, and Wangerin (2016), managers with higher ability to manage resources efficiently are likely to be involved in greater tax avoidance. This is based on three arguments. Firstly, higher-ability managers have a good understanding of how to identify and exploit tax planning opportunities. Secondly, higher ability managers are likely to choose a reduction in tax costs compared to operational cost, 
because the former do not have a direct adverse effect on the firm's operations (Dyreng, Hanlon, \& Maydew, 2010). Thirdly, managers with higher ability try to make cash tax savings that are redeployed to more productive uses through profitable investment activities. Furthermore, Koester et al. (2016) succeeded in providing empirical evidence that managers with a higher ability are more likely to engage in tax aggressiveness by reducing tax cash payments. Therefore, we argue that FFs managed by experienced managers can potentially reduce tax aggressiveness or vice versa. This leads to our hypothesis:

H2: Family firms' top managers' experience positively affects firms' tax aggressiveness.

FFs' closeness to governments is an example of organizational resources. Closeness to governments or political connections is a pervasive phenomenon in transitioning and developing countries (Wu et al., 2012). The political connection can take various forms such as the presence of at least one government official in a firm's ownership structure, the board of director, or audit committee (Khlif \& Amara, 2018). Firms with close connections to governments will arguably receive special treatment such as loans or a lowered risk of tax inspection (Hanny \& Niandari, 2018). Such special treatments imply that politically connected firms are more tax aggressive than firms distant to government. Besides, firms use tax aggressiveness to reduce political cost (Kim \& Zhang, 2015).

Previous studies demonstrate that politically connected firms tend to enjoy tax benefits by paying lower Effective Tax Rate (ETR; Wu, Wu, Zhou, \& Wu, 2012). In the same vein, politically connected firms are more tax aggressive as measured by book-tax differences than non-politically connected firms (Aswadi, Wahab, Ariff, Marzuki, \& Sanusi, 2017; Kim \& Zhang, 2011). Based on this discussion, we propose the following hypothesis:

H3: Family firms' political connections positively affect firms' tax aggressiveness.

\section{MATERIAL AND METHODS}

This study uses an explanatory method because it seeks to explain effects of the three firm resources based on RBV categories - firm size, top manager's experience, and closeness with the government - on tax aggressiveness behaviour and focus in the family firm context in emerging countries.

The study uses data from the World Bank's Productivity and Investment Climate Survey that covers several issues, including taxation. The survey was held in 2010-2018 with the total of 136889 respondents. The data collection method used by the World Bank is a field survey through face-to-face interviews with respondents consisting of firm owners, top managers, accountants, and human resources specialists. Target firm data is sourced from the master list of companies obtained from the country's statistical office and other government agencies such as tax or business licensing authorities. For the sake of sample representation, the selection of surveyed companies is based on multistage random sampling based on firm size, business sector, and geographic region within a country.

As our sample, we only use FFs that meet several criteria; firstly, firms with single ownership of more than $50 \%$ of total ownership (Bednarz et al., 2017). Next, we only use observations from emerging countries as defined by the IMF, namely Argentina, Bangladesh, Brazil, Bulgaria, Chile, China, Colombia, Hungary, India, Indonesia, Malaysia, Mexico, Pakistan, Peru, Filipina, Poland, Romania, Russia, South Africa, Thailand, Turkey, Ukraine, 
and Venezuela. Secondly, the formal firm considering the focus of this study is tax compliance (Gokalp, Lee, \& Peng, 2017). Thirdly, outliers are not included. The above criteria produce the final sample of 19848 firms.

The study involves tax aggressiveness as the response variable, along with firm size, top manager's experience, and closeness to government as predicting variables and several control variables. Tax aggressiveness is measured with the response to the question "Over the last year, how many times was this establishment either inspected by tax officials or required to meet with them?" We use the question related to tax inspection because more frequent tax inspections indicate that taxpayers have more tax-related problems (OECD, 2014). Thus, firms inspected by tax officials more frequently are likely more tax aggressive.

Table 1. List of variable measurement

\begin{tabular}{|l|l|}
\hline \multicolumn{1}{|c|}{ Variable } & \multicolumn{1}{c|}{ Measurement } \\
\hline Tax aggressiveness (TC) & $\begin{array}{l}\text { Measured with the frequency of tax inspections. Classified into three } \\
\text { categories, 1 = never inspected, 2 = 1-30 times inspected, and 3 = in- } \\
\text { spected more than 30 times. }\end{array}$ \\
\hline Firm size (SIZE) & $\begin{array}{l}\text { Classified into three categories, 1 = small (the firm has up to 20 em- } \\
\text { ployees), 2 = medium (the firm has 20-99 employees), and 3 = large } \\
\text { (the firm has more than 100 employees). }\end{array}$ \\
\hline $\begin{array}{l}\text { Top Manager's Experience } \\
\text { (EXP) }\end{array}$ & $\begin{array}{l}\text { Measured with how long the top manager worked in the same indus- } \\
\text { try as the one in which the firm operates. }\end{array}$ \\
\hline $\begin{array}{l}\text { Closeness to the Govern- } \\
\text { ment (GOV) }\end{array}$ & $\begin{array}{l}\text { A dummy variable that equals 1 if the firm seeks to secure govern- } \\
\text { ment contracts and 0 if otherwise. }\end{array}$ \\
\hline Industry (IND) & $\begin{array}{l}\text { A dummy variable that equals 1 if the firm operates in the manufac- } \\
\text { turing industry and 0 if otherwise. }\end{array}$ \\
\hline Firm age (AGE) & $\begin{array}{l}\text { Measured with the natural logarithmic value of the number of the } \\
\text { firm's operating years. }\end{array}$ \\
\hline
\end{tabular}

Source: own study.

We measure firm size with the number of employees. Based on the classification of company size conducted by the World Bank (2009), we classify firms into three categories: small (up to 19 employees), medium (20-99 employees), and large (more than 100 employees). Next, the top manager's experience is measured with his/her years of experience in managing similar firms. Next, we measure closeness to government with the question of "Over the last year, has this establishment secured or attempted to secure a government contract?"

We use both industry-level and firm-level control variables. The industry-level control variable is a dummy variable that equals one if the firm is in the manufacturing industry and zero if otherwise. Meanwhile, firm age is the firm-level control variable.

Because the dependent variable of this study is measured with ordinal scale, we test our hypotheses by using the following ordered probit model (OPM) equation (Greene, 2018, pp. 111):

$$
y *=\beta^{\prime} x+\varepsilon
$$

in which $y *$ is the response variable, $x$ is the vector of predictors variable, $\beta$ is a vector of unknown parameters to be estimated, and $\varepsilon_{n i}$ is the random error term capturing the effect of unobserved factors, which is assumed to follow a normal distribution with zero 
mean and unit variance. The response variable $(y *)$ of this study (tax aggressiveness) is measured by using three levels, namely (1) low tax aggressiveness, (2) moderate tax aggressiveness, and (3) high tax aggressiveness.

$$
y(T A)=\left\{\begin{array}{l}
1, \text { if } T A<\omega 1 \\
2, \text { if } \omega 1 \leq T A \leq \omega 2 \\
3, \text { if } T A>\omega 2
\end{array}\right.
$$

Thus, the following is the equation

$$
T A * i=\beta 0+\beta 1 S I Z E i+\beta 2 E X P i+\beta \Sigma G O V i+\beta \Sigma I N D i+\beta \Sigma A G E i+\varepsilon i
$$

in which TA is the tax aggressiveness level, EXP is top manager's experience, SIZE refers to firm's size classified into three measures (small, medium, and large). Further, GOV is a dummy variable that equals 1 if the firm has close ties with the government and 0 if otherwise. Similarly, IND is also a dummy variable that equals 1 if the firm belongs to the manufacturing industry and 0 if otherwise, while AGE is firm's age.

\section{RESULTS AND DISCUSSION}

\section{Descriptive Statistics}

The descriptive statistics of 19848 observations reveal that $46.68 \%$ of total observations fall into the non-tax aggressive category, while $51.96 \%$ of total observations fall into moderately aggressive. Only relatively few firms $-1.36 \%$ of total observations - fall into the very aggressive category.

Small and medium firms dominate the observations. Specifically, $40.84 \%$ of total observations are small firms, while $37.09 \%$ of total observations are medium firms. Meanwhile, $22.07 \%$ of total observations are large firms.

Table 2. Descriptive statistics of dependent, explanatory, and control variables

\begin{tabular}{|l|r|r|}
\hline \multicolumn{1}{|c|}{ Category } & \multicolumn{1}{|c|}{$\mathbf{n}$} & \multicolumn{1}{c|}{ Proportion (\%) } \\
\hline Tax Aggressiveness & & 46.68 \\
\hline Not aggressive & 9265 & 51.96 \\
\hline Moderately aggressive & 269 & 1.36 \\
\hline Very aggressive & & 40.84 \\
\hline Firm Size & 8107 & 37.09 \\
\hline Small & 7361 & 22.07 \\
\hline Medium & 4380 & \\
\hline Large & & \\
\hline Closeness to the Government & 16571 & 16.51 \\
\hline No & 3277 & 64.77 \\
\hline Yes & & 35.23 \\
\hline Industry Type & 12855 & \\
\hline Manufacture & 6993 & \\
\hline Non-Manufacture & & \\
\hline Source: own study. & &
\end{tabular}


In terms of closeness to government, $83.49 \%$ of total observations show no closeness to government as indicated by firms' efforts to secure contracts from governments. Furthermore, $64.77 \%$ of total observations are manufacturing firms and the rest are non-manufacturing firms.

The correlation matrix demonstrates the relationship between firm size, top manager's experience, closeness to government, industry type, and firm age. Table 3 also shows no high correlation coefficients between independent variables, thus indicating no serious multicollinearity issue. Thus, the results suggest that all independent variables can be used for our ordered probit analysis.

Table 3. Spearman correlation matrix of explanatory and control variables

\begin{tabular}{|l|l|l|l|l|l|}
\hline \multicolumn{1}{|c|}{ Variables } & \multicolumn{1}{|c|}{ (1) } & \multicolumn{1}{|c|}{ (2) } & \multicolumn{1}{|c|}{ (3) } & (4) & (5) \\
\hline Firm Size(1) & 1.000 & & & & \\
\hline \multirow{2}{*}{ Top Manager's Experience (2) } & $\begin{array}{l}0.0802 \\
0.000^{* * *}\end{array}$ & 1.000 & & & \\
\hline \multirow{2}{*}{ Closeness to Government (3) } & $\begin{array}{l}0.0428 \\
0.000^{* * *}\end{array}$ & $\begin{array}{l}0.0471 \\
0.000^{* * *}\end{array}$ & 1.000 & & \\
\hline \multirow{2}{*}{ Industry Type (4) } & $\begin{array}{l}0.1777 \\
0.000^{* * *}\end{array}$ & $\begin{array}{l}0.0899 \\
0.000^{* * *}\end{array}$ & $\begin{array}{l}-0.0548 \\
0.000^{* * *}\end{array}$ & 1.000 & \\
\hline \multirow{2}{*}{ Firm Age (5) } & $\begin{array}{l}0.2108 \\
0.000^{* * *}\end{array}$ & $\begin{array}{l}0.2743 \\
0.000^{* * *}\end{array}$ & $\begin{array}{l}0.0351 \\
0.000^{* * *}\end{array}$ & $\begin{array}{l}0.1635 \\
0.000^{* * *}\end{array}$ & 1.000 \\
\hline
\end{tabular}

Notes $* * * p<0.01$

Source: own elaboration in Stata.

\section{Ordered Probit Model (OPM) Analysis}

Table 4 shows that the pseudo $\mathrm{R}^{2}$ value is 0.0285 , indicating that $2.91 \%$ of the variant proportion of tax aggressiveness variable is explained by the predicting variables. Similar to research in the field of health - in behavioral studies - the low pseudo $R^{2}$ is acceptable because numerous factors determine a behavior (Martin, 2013). Furthermore, Martin (2013) also states that the main point lies in reliable relationships; especially in studies involving large sample sizes. The $\chi^{2}$ probability of the model is $<0.0001$, implying that at least one of the regression coefficients in the model is not equal to zero. The OPM does not produce an intercept as a constant but a cutpoints value (/cut) as the determinant of tax aggressiveness when the firm size, top manager's experience, and political connection variables are equal to zero. The cutpoints 1 value of 0.5168 indicates that tax aggressiveness will be lower if variables other than the research variables are 0.5168 or lower and, conversely, they will be higher if variables other than the research variables are 3.716 (cutpoints 2) or higher. If the values of other variables fall within the range of 0.5168-3.716, then tax aggressiveness is moderate.

Next, the coefficient of firm size is 0.263 ( $p$-value $<0.000$ ), suggesting that larger firms tend to engage in a greater level of tax aggressiveness ( $H_{1}$ is supported). The results also show that managers with longer experience in the same industry usually engage in greater tax aggressiveness ( $\mathrm{H}_{2}$ is supported), as indicated by its coefficient value of 0.020 ( $p$-value 0.034 ). Furthermore, the coefficient value of closeness to government is 0.367 ( $p$-value < 0.000 ), also indicating that firms with close ties with governments tend to exhibit a greater level of tax aggressiveness ( $\mathrm{H}_{3}$ is supported). Thus, firms have the option to engage in 
greater tax aggressiveness due to larger firm size, longer manager's experience, and close ties with governments.

For control variables, the industry type and firm age variables are positively associated with tax aggressiveness (coef. 0.030 p-value 0.060; coef. 0.002 p-value 0.033 ). Thus, besides the variables of interest - firm size, top manager's experience, and closeness to government - industry type and firm age as control variables also affects tax aggressiveness.

Table 4. OPM estimates of tax aggressiveness

\begin{tabular}{|l|c|c|}
\hline \multicolumn{1}{|c|}{ Variable } & Coef & p-value \\
\hline Firm Size & 0.263 & $0.000^{* * *}$ \\
\hline Top Manager's Experience & 0.020 & $0.034^{* *}$ \\
\hline Closeness to Government & 0.367 & $0.000^{* * *}$ \\
\hline & & \\
\hline Control Variable & & $0.060^{*}$ \\
\hline Industry Type & 0.030 & $0.033^{* *}$ \\
\hline Firm Age & 0.002 & \\
\hline & & \\
\hline /cut1 & 0.517 & \\
\hline /cut2 & 3.717 & \\
\hline
\end{tabular}

Notes: the number of observations $=19848 ;$ Wald $\chi 2=809.81 ;$ probability $\chi 2=0.0000 ;$ Pseudo $R 2=0,0291$

${ }^{*} \mathrm{p}<0.1 ; * * \mathrm{p}<0.05 ; * * * \mathrm{p}<0.01$.

Source: own elaboration in Stata.

\section{Discussion}

The study demonstrates that larger FFs in emerging countries exhibit a greater level of tax aggressiveness. The results are in line with previous studies that show that firm size is associated with the level of tax aggressiveness (Irianto et al., 2017; Ogbeide, 2017; Wang et al., 2014). FFs with an increasingly large size are not balanced with awareness to meet their tax obligations but, instead, motivated to make tax avoidance. Larger firm size motivates FFs to not only focus on family values but also on profit maximization, including through tax aggressiveness. Larger FFs in emerging countries are likely to make use of their financial advantages to influence parties related to taxation and the complexity of their transactions to facilitate tax aggressiveness.

We also observe that managers who have longer experience in the same industry tend to engage in greater tax aggressiveness. The finding implies that - in FFs in emerging countries - managers with long experience in similar industries also have a better experience in engaging in aggressive tax behaviour. Managers with longer experience tend to have a higher ability to manage various aspects of FFs, including taxation aspects. This can lead to the behaviour of managers to carry out tax aggressiveness, which may seek cash savings that can be used as an alternative source of financing firm development. Cash obtained from tax savings will be allocated in firm projects that are expected to generate a positive return on investment (Koester, et al., 2016). In FFs, managers' longer experience will shift the objectives of owning families from building FFs in societies into satisfactory income to continue the business.

The likely explanation of our results with previous studies on non-FFs - both for firm size and top manager's experience - is the difference in FFs' stages. FFs have four phases, 
namely development, management, transformation, and preservation. During the development and management phases, owning families still likely maintain their ideal objectives of owning FFs (family values and reputation). Thus, FFs will thoroughly analyse impacts of tax aggressiveness on firms' long-term wealth and reputation (Isakov \& Weisskopf, 2015; Sánchez-Marín et al., 2016). However, during the transformation and preservation phases - characterised by professionalism in managing firms - the ideal objectives of owning families will arguably wane, and FFs will mostly focus on maximizing profits because of their obligations to bequeath FFs' assets to following generations (Casson, 1999).

In terms of closeness to government, our results show a similar result to other studies focusing on non-FFs. Thus, firms with close ties with governments exhibit a greater level of tax aggressiveness. Our study supports the findings of Aswadi et al. (2017), Kim and Zhang (2015), and Wu et al. (2012). FFs' closeness to government is a component of organizational resources that cause these firms to receive special treatments, such as receiving loans and having a low risk of tax inspection. The argument implies that politically connected firms tend to be more tax aggressive than non-politically connected firms.

The results elaborate on the conflicting results of previous studies on tax aggressiveness of FFs. In particular, several studies show that FFs are more aggressive (Martinez \& Ramalho, 2014; Chen, Chen, Cheng, \& Shevlin, 2010; Mafrolla \& Amico, 2016; Steijvers \& Niskanen, 2014), while others indicate that FFs are not aggressive (Pierk, 2016; Gaaya, Lakhal, \& Lakhal, 2017). FFs' aggressiveness, especially in emerging countries, is affected by their resources, measured by this study using firm size, top manager's experience, and closeness to government. Thus, FFs' heterogeneous and unique resources are determinants of tax aggressiveness as explained by the RBV.

However, our study finds that larger firm size, more experienced top manager, and closeness to government exhibit a greater level of tax aggressiveness. Thus, besides creating a competitive advantage - as suggested by Peteraf and Barney (2003) - firms' resources can also motivate firms to exhibit dysfunctional behaviour such as tax aggressiveness. Consequently, in minimizing tax aggressiveness, FFs in emerging countries need to manage their resources productively so as to create valuable, rare, inimitable, and non-substitutable resources.

\section{CONCLUSIONS}

Management literature often mentions the important role of FFs in developing countries such as drivers of economic growth and job creation and economic buffering during crises, However, the question arises as to how far FFs comply with their tax obligations and whether the strength of resources owned by FFs leads to tax compliance or tax aggressiveness, in which tax becomes the main source of financing for developing country development. This study has empirically analysed FFs' tax aggressiveness based on their resources by using 19848 sample firms in emerging countries. The results demonstrate that FFs with resources of firm size, top manager's experience, and closeness to government exhibit greater levels of tax aggressiveness.

Therefore, our article offers implications relevant for academicians, policymakers, and practitioners. More specifically, the study offers a better understanding of FFs' tax aggressiveness by using the RBV, which is relatively understudied in the literature. Currently, the RBV as initiated by Barney (1991), offers a framework of the strategic role of firms' resources 
- which consist of physical capital resources, human capital resources, and organizational resources that are valuable, rare, inimitable, and non-substitutable (Kabue \& Kilika, 2016) as the basis of sustainable competitive advantage. However, as our study finds, the RBV also offers the framework as the basis of FFs' tax aggressiveness behaviour. Our results indicate that $51.34 \%$ of FFs in emerging countries tend to engage in tax aggressiveness. The findings suggest that governments of emerging countries must pay more attention to the behaviour of FFs in meeting their tax obligations. Governments must continue to increase the supervision of financial reporting of FFs through audit activities - especially for larger FFs and FFs led by more experienced top managers - so as to enhance tax compliance, because these firms potentially engage in greater levels of tax aggressiveness. Moreover, our study supports previous studies (Aswadi et al., 2017; Kim \& Zhang, 2015; Wu et al., 2012) that find that FFs with closeness to government tend to use this close relationship for tax aggressiveness. The findings suggest that government officers must remain objective in levying taxes on all FFs, regardless of their closeness to government. This requires law enforcement, as governments must also impose strict sanctions on officers who do not act objectively. Meanwhile, practical implications for business actors are that top managers of FFs should prioritize the use of their resources to increase their firms' competitive advantage and reputation to support long-term firm existence rather than for the benefit of saving money through activities intended to avoid tax obligations and payments.

\section{REFERENCES}

Aswadi, E., Wahab, A., Ariff, A.M., Marzuki, M.M., \& Sanusi, Z.M. (2018). Political connections, corporate governance, and tax aggressiveness in Malaysia. Asian Review of Accounting, 25(3), 424451. https://doi.org/10.1108/ARA-05-2016-0053

Bednarz, J., Bieliński, T., Wołowik, A.N., \& Otukoya, A. (2017). Sources of the competitive advantage of family enterprises: An international approach focusing on China, Nigeria and Poland. Entrepreneurial Business and Economics Review, 5(2), 124-142. https://doi.org/10.15678/EBER.2017.050207

Barney, J. (1991). Firm resources and sustained competitive advantage. Journal of Management, 17, 99-120.

Bjuggren, P., \& Sud, L.G. (2005). Organization of transfers of small and medium-sized enterprises within the family. Family Business Review, 18(4), 305-320. https://doi.org/10.1111/j.17416248.2005.00050.x

Bonilla, C.A., Sepulveda, J., \& Carvajal, M. (2010). Family ownership and firm performance in Chile. Family Business Review, 23, 148-154.

Casson, M. (1999). The economics of the family firm. Scandinavian Economic History Review, 47(1), 10-23.

Cabrera-Suárez, M.K., Déniz-Déniz, M., \& Martín-Santana, J.D. (2014). The setting of non-financial goals in the family firm: The influence of family climate and identification. Journal of Family Business Strategy, 5(3), 289-299. https://doi.org/10.1016/j.jfbs.2014.05.003

Chen, S., Chen, X., Cheng, Q., \& Shevlin, T. (2010). Are Family Firms more tax aggressive than nonFamily Firms?. Journal of Financial Economics, 95, 41-61.

Chrisman, J.J., Chua, J.H., \& Steier, L. (2005). Sources and consequences of distinctive familiness: An introduction. Entrepreneurship: Theory and Practice, 29, 237-247. https://doi.org/10.1111/j.1540-6520.2005.00080.x

Dyreng, S., Hanlon, M., \& Maydew,E. (2008). Long-run corporate tax avoidance. The Accounting Review, 83, 61-82. 
Dyreng, S., Hanlon, M., \& Maydew, E. (2010). The effects of executives on corporate tax avoidance. The Accounting Review, 85(4),1163-1189. https://doi.org/10.2308/accr.2010.85.4.1163

Enz, C.A. (2008). Creating a competitive advantage by building resource capability: The case of Outback Steak House, Korea. Cornell Hospitality Quarterly, 49, 73-78. http://dx.doi.org/10.1177/193896550731164

Eilbert, H., \& Parket, I.R. (1973). The current status of corporate social responsibility. Business Horizons, 16, 5-14.

Gaaya, S., Lakhal, N., \& Lakhal, F. (2017). Does family ownership reduce corporate tax avoidance? The moderating effect of audit quality. Managerial Auditing Journal, 32(7), 731-744. https://doi.org/10.1108/MAJ-02-2017-1530

Gedajlovic, E., Carney, M., Chrisman, J., \& Kellermanns, F. (2012). The adolescence of family firm research taking stock and planning for the future. Journal of Management, 38, 1010-1037.

Gokalp, O.N., Lee, S.H., \& Peng, M.W. (2017), Competition and corporate tax evasion: An institutionbased view, Journal of World Business, 52(2), 258-269. https://doi.org/10.1016/j.jwb.2016.12.006

Greene, W.H. (2018). Econometric analysis: Global Edition (8th Edition). United Kingdom: Pearson.

Hanny R., \& Niandari, N. (2018). Tax avoidance practice: political connection, firm characteristics and audit quality test at banking Industrial in Indonesia. International Journal of Business Management and Economic Research, 9, 1296-1303.

Huybrechts, J., Voordeckers, W., Lybaert, N., \& Vandemaele, S. (2016). The distinctiveness of familyfirm intangibles: A review and suggestions for future research. Journal of Management \& Organization, 17(2), 268-287. https://doi.org/10.1017/s1833367200001656

Irianto, B.S., Sudibyo, Y.A., \& Wafirli, A. (2017). The influence of profitability, leverage, firm size and capital intensity towards tax avoidance. International Journal of Accounting and Taxation, 5(2), 33-41.

Isakov, D., \& Weisskopf, J.P. (2015). Pay-out policies in founding Family Firms. Journal of Corporate Finance, 33, 330-344.

Kabue, L., \& Kilika, J. (2016). Firm resources, core competencies and sustainable competitive advantage: An Integrative Theoretical Framework. Journal of Management and Strategy, 7(1), 98-108

Khlif, H., \& Amara, I. (2018), Financial crime, corruption and tax evasion: a cross-country investigation. Journal of Money Laundering Control, 26(2), 401-411. https://doi.org/10.1108/JFC-012018-0004

Koester, A., Shevlin, T., \& Wangerin, D. (2016). Does operational efficiency spill over onto the tax return?. Management Science, 63(10), 3285-3310. http://dx.doi.org/10.1287/mnsc.2016.2510

Kim, B., Li, Y., \& Zhang, L. (2011). Corporate tax avoidance and stock price crash risk: a firm-level analysis. Journal of Financial Economics, 100(3), 639-662.

Kim, C., \& Zhang, L. (2015). Corporate political connections and tax aggressiveness. Contemporary Accounting Research, 3(1), 78-114.

Kim, D., Kandemir, D., \& Cavusgil, S.T. (2004). The role of family conglomerates in emerging markets: what western companies should know. Thunderbird International Business Review, 46, 13-38.

Lucky, E.I., Minai, M.S., \& Isaiah, A.O. (2011). A conceptual framework of family business succession: bane of family business continuity. International Journal of Business and Social Science, 2, 106-133.

Madhani, P.M. (2016). Firm size, corporate governance and disclosure practices: Inter-relations. SCMS Journal of Indian Management, 13(2), 17-39. 
Mafrolla, E., \& Amico, E.D. (2016). Tax aggressiveness in Family Firms and the non-linear entrenchment effect. Journal of Family Business Strategy, 7(3), 178-184. https://doi.org/10.1016/j.jfbs.2016.08.003

Martin, K.G. (2013). Can a regression model with a small R-squared be useful?. The analysis factors. Retreived from https://cpb-us-w2.wpmucdn.com on May, 29, 2020.

Martinez, A.L. (2017). Tax aggressiveness: a literature survey. Revista de Educação e Pesquisa em Contabilidade Journal of Education and Research in Accounting, 11(6), 104-121. http://dx.doi.org/10.17524/repec.v11i0.1724

Martinez, A.L., \& Ramalho, G.C. (2014). Family Firms and tax aggressiveness in Brazil. International Business Research, 7(3), 129-136. https://doi.org/10.5539/ibr.v7n3p129

Michalisin, M.D., Smith, R., \& Douglas, M.K. (1997). In search of strategic assets. The International Journal of Organizational Analysis, 5(4), 360-387.

Mills, L., Nutter, S., \& Schwab. (2013). The effect of political sensitivity and bargaining power on taxes: Evidence from federal contractors. The Accounting Review, 88, 977-1005.

Monticelli, J.M. (2017). Family business in emerging and developed economies: similarities and differences. Conference: International Family Research Academy. Retrieved from https://www.researchgate.net/publication/320024714 on May 20, 2020.

Nicodème, G. (2007). Do larges companies have lower effective corporate tax rates? A European survey. A European survey (Centre Emile Bernheim Working Paper No. 07/001). (Centre Emile Bernheim Working Paper No. 07/001). Retreived from https://core.ac.uk/display/6491749 on May 20, 2020.

Peni, E. (2014). CEO and chairperson characteristics and firm performance. Journal of Management \& Governance, 18(1), 185-205.

Peteraf, M. \& Barney, J. (2003). Unravelling The Resource-Based Tangle. Managerial and Decision Economics, 24, 309-323. https://doi.org/10.1002/mde.1126

Pierk, J. (2016). Are private firms really more tax aggressive than public firms? (WU International Taxation Research Paper Series No. 2016-02). Retrieved from SSRN: https://ssrn.com/abstract=2758756 or http://dx.doi.org/10.2139/ssrn.2758756_on May 20, 2020.

Rego, S.O. (2003). Tax avoidance activities of U.S. multinational corporations. Contemporary Accounting Research, 20(4), 805-833.

Saidu., S. (2019). CEO characteristics and firm performance: focus on origin, education and ownership. Journal of Global Entrepreneurship Research, 9, 8-15. https://doi.org/10.1186/s40497019-0153-7

Sánchez-Marín, G., Portillo-Navarro, M.J., \& Clavel, N.J.G. (2016). The influence of family involvement on tax aggressiveness of Family Firms. Journal of Family Business Management, 6(2), 1-46.

Schulze, W.S., \& Gedajlovic, E.R. (2010). Whither family business?. Journal of Management Studies, 47, 191-204.

Smulders, S., Stiglingh, M., Franzsen, R., \& Fletcher, L. (2017). Determinants of external tax compliance costs: Evidence from South Africa. South African Journal of Accounting Research, 31(2), 134-150.

Siegfried, J.J. (1972). The publishing of economic papers and its impact on graduate faculty ratings; 1960-69. Journal of Economic Literature, 10(1), 31-49.

Stanwick, P.A., \& Stanwick, S.D. (2003). CEO and ethical reputation: visionary or mercenary. Management Decision, 41(10), 1050-1057.

Steijvers, T., \& Niskanen, M. (2014). Tax aggressiveness in private family firms: An agency perspective. Journal of Family Business Strategy, 144, 1-11. 
Wade, J.B., Porac, J.F. Pollock, T.G., \& Graffin, S.D. (2018). Star CEOs: benefit or burden.? Organizational Dynamics, 37(2), 203-210. https://doi.org/10.1016/j.orgdyn.2008.02.007

Waluyo, W. (2017). Enterprise size, enterprise age, and enterprise growth on corporate social responsibility in Indonesia: the case of real estate companies. European Research Studies Journal, 20(4A), 360-369.

Wang, Y., Campbell, H., \& Johnson. D.(2014). Determinants of effective tax rate of China publicly listed companies. International Management Review, 10(1), 10-20.

Welter, F. (2011). Contextualizing entrepreneurship-conceptual challenges and ways forward. Entrepreneurship Theory and Practice, 35, 165-184.

World Bank (2009). Enterprise survey and indicator surveys: sampling methodology. Retrieved from www.enterprisesurveys.org on March 17, 2018.

Wu, W., Wu, C., Zhou, C., \& Wu, J. (2012). Political connections, tax benefits and firm performance: Evidence from China. Journal of Accounting and Public Policy 31, 277-300.

Zellweger, T.M., Eddleston, K.A., \& Kellermanns, F.W. (2010). Exploring the concept of familiness: Introducing family firm identity. Journal of Family Business Strategy, 1, 54-63. http://dx.doi.org/10.1016/j.jfbs.2009.12.003

Zellweger, T. (2017). Managing the family business: Theory and Practice. Cheltenham, UK: Edward Elgar Publishing.

\section{Authors}

The contribution of co-authors is equal and can be expressed as $25 \%$ per each of the authors: $U$. S. Sucahyo prepared the introduction and literature review, T.W. Damayanti prepared the literature review and the material and methods section, R. Prabowo prepared data, the statistical analysis, and discussion, while S. Supramono drew conclusions, proofread, and supervised the paper for publication.

\section{Usil Sis Sucahyo}

Assistant Professor at the Department of Accounting, Faculty of Economics and Business, Universitas Kristen Satya Wacana. His research interests include cost accounting, accounting for nonprofit organizations, and management control systems. Among other places, Usil Sis Sucahyo published his articles in International Journal of Recent Technology and Engineering.

Correspondence to: Dr. Usil Sis Sucahyo, Faculty of Economics and Business, Universitas Kristen Satya Wacana, Jln Diponegoro 52, Salatiga, Indonesia, e-mail: usil.sucahyo@uksw.edu ORCID (1) http://orcid.org/0000-0001-8552-7909

\section{Theresia Woro Damayanti}

Associate Professor at the Department of Accounting, Faculty of Economics and Business, Universitas Kristen Satya Wacana. She is also the head of the Department of Accounting. Her research interests include taxation and tax system evaluation. She was the author and co-author of several articles in reputable international journals such as Business: Theory and Practice, Gender in Management: An International Journal, Montenegrin Journal of Economics, and Polish Journal of Management Studies. Correspondence to: Dr. Thresia Woro Damayanti, Faculty of Economics and Business, Universitas Kristen Satya Wacana, JIn Diponegoro 52, Salatiga, Indonesia, e-mail: theresia.damayanti@uksw.edu ORCID (1) http://orcid.org/0000-0002-4065-3562 


\section{Ronny Prabowo}

Associate Professor at the Department of Accounting, Faculty of Economics and Business, Universitas Kristen Satya Wacana. His research interests include cost accounting and taxation. He published papers in several national and international scientific journals such as Business: Theory and Practice and European Accounting Review, among other places.

Correspondence to: Ronny Prabowo, PhD, Faculty of Economics and Business, Universitas Kristen Satya Wacana, Jln Diponegoro 52, Salatiga, Indonesia, e-mail: ronny.prabowo@uksw.edu ORCID (ㄴ) http://orcid.org/0000-0003-0785-3156

\section{Supramono Supramono}

Professor in Finance at the Department of Management, Faculty of Economics and Business, Universitas Kristen Satya Wacana. His research interests include behavioural finance, capital market, corporate finance, and corporate tax. He published several articles in reputable international journals as Montenegrin Journal of Economics, Central European Management, Journal Gender in Management: An International Journal, Business: Theory and Practice, and Polish Journal of Management Studies.

Correspondence to: Prof. Supramono, Faculty of Economics and Business, Universitas Kristen Satya Wacana, Jln Diponegoro 52, Salatiga, Indonesia, e-mail: supramono@uksw.edu ORCID (1) http://orcid.org/0000-0002-2110-0671

\section{Acknowledgements and Financial Disclosure}

The article came into being within the project No.471/Penel./Rek./10/V/2019 for Fundamental Research in Entrepreneur and Business Management, financed by Universitas Kristen Satya Wacana, Salatiga, Indonesia, in 2019.

\section{Copyright and License}

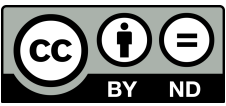

This article is published under the terms of the Creative Commons

Attribution - NoDerivs (CC BY-ND 4.0) License

http://creativecommons.org/licenses/by-nd/4.0/

Published by Cracow University of Economics - Krakow, Poland

Ministry of Science The copyediting and proofreading of articles in English is financed in the framework and Higher Education of contract No. 913/P-DUN/2019 by the Ministry of Science and Higher Education 
